Andrzej Kaleta Instytut Bibliotekoznawstwa i Dziennikarstwa Uniwersytet Jana Kochanowskiego w Kielcach e-mail: akaleta@kielce.opoka.org.pl

\title{
Stanowisko władz kościelnych wobec ruchu ludowego w Galicii na przykładzie społecznej i wydawniczej działalności księdza Stanistawa Stojałowskiego
}

STRESZCZENIE: Ksiądz Stanisław Stojałowski był wybitnym przedstawicielem ruchu ludowego aktywnego w XIX w. w galicyjskim środowisku chłopskim. Uczestniczył w powołaniu do istnienia Stronnictwa Chrześcijańsko-Ludowego, założył m.in. Towarzystwo Kółek Rolniczych. Ks. S. Stojałowski, doceniając zalety prasy w dziedzinie kształtowania świadomości i postaw społecznych, w $1875 \mathrm{r}$. objął redakcję „Wieńca” i „Pszczółki”. Te dwa periodyki odegrały istotną rolę w jego akcji ludowej. Nagłaśniane na ich łąmach niezależne poglądy w kwestiach społecznych i ekonomicznych sprowadziły na niego poważne szykany, a także utrudnienia w realizowaniu działalności wydawniczej.

SŁoWA KLUCzowe: „Pszczółka”, „Wieniec”, duchowieństwo katolickie, działalność wydawnicza, Galicja, ruch ludowy, Stojałowski Stanisław (1845-1911), XIX-XX w.

Drzełom XIX i XX w. przyniósł na ziemiach polskich poważne zmiany postaw politycznych i społeczno-religijnych. W sposób szczególny zaznaczyły się one w galicyjskim środowisku chłopskim. Wiązało się to $\mathrm{z}$ rozwojem na tych terenach, w ostatnim dwudziestopięcioleciu XIX w., ruchu ludowego przy udziale duchowieństwa katolickiego. Zagadnienia 
społeczne stały się bowiem przedmiotem licznych listów pasterskich biskupów galicyjskich. Nauczanie abp. lwowskiego Józefa Bilczewskiego, bp. przemyskiego Józefa Pelczara czy abp. obrządku ormiańskiego Józefa Teodorowicza stało się wykładem katolickiej nauki społecznej zgodnym ze wskazaniami papieża Leona XIII ${ }^{1}$. Biskupi zachęcali księży do większego zaangażowania się w sprawy społeczne i gospodarcze; czyniła to również prasa katolicka².

Wśród wielu duchownych, których można uznać za prekursorów powyższej aktywności Kościoła, był jezuita, ks. Stanisław Stojałowski. Przełożeni, po święceniach wysłali go na studia do Belgii (1873-1874), gdzie zetknął się z rozwijającym się tam ruchem społeczno-chrześcijańskim. Po powrocie do kraju wystąpił z Towarzystwa Jezusowego (dalej: SJ), inkardynując się do archidiecezji lwowskiej, gdzie rozwinął działalność społeczno-polityczną. Ks. Stojałowski nie był teoretykiem, lecz praktycznym działaczem społecznym. Ponieważ najbardziej zacofaną i najuboższą grupę społeczeństwa galicyjskiego stanowili mieszkańcy wsi, zaczął swą pracę od zwrócenia uwagi na tę grupę ludzi. Zaowocowało to $\mathrm{w}$ praktyce przeniesieniem na grunt wsi galicyjskiej zasad ruchu społeczno-chrześcijańskiego, z jakimi zapoznał się w czasie swoich studiów na Zachodzie Europy. W 1879 r. założył Towarzystwo Ludowe Oświaty i Pracy. Wzorował się w tym przypadku na organizacjach robotniczych działających w poznańskim, a zakładanych przez Maksymiliana Jackowskiego. W 1882 r. Towarzystwo zostało przekształcone na Towarzystwo Kółek Rolniczych. Po siedmiu latach działalności liczba kółek doszła do 1374, skupiając ok. 61000 członków. Do pierwszej wojny światowej powstało 2081 kółek z 82000 członków³ . W 1894 r. kółka rolnicze istniały w 70 powiatach Galicji, przy czym w wielu przypadkach kierowali nimi księża. Inną formą działalności społeczno-gospodarczej Stojałowskiego było zakładanie sklepów wiejskich. Pomysłodawcy zależało na ukróceniu lichwy towarowej na wsi. O skali zjawiska świadczy fakt, że w $1892 \mathrm{r}$. w Galicji funkcjonowały 522 tego rodzaju instytucje handlowe ${ }^{4}$. Rok

1 W. Najdus, Szkice z historii Galicji, t. 2, Warszawa 1958, s. 118.

2 B. Bogucki, Inteligencja wobec ruchu społeczno-katolickiego, „Głos Narodu” 1906, nr 17 , s. 7

3 A. Górnicz, Kółka rolnicze na ziemiach polskich w okresie zaborów, „Roczniki Dziejów Ruchu Ludowego" 1966, nr 8, s. 30-34.

4 Kronika. Przemówienie ks. Stojałowskiego, „Głos Narodu” 1894, nr 20, s. 12. 
1890 zaowocował powołaniem do życia Ludowego Towarzystwa Zakupu i Ochrony Ziemi. Powyższa inicjatywa przysłużyła się do powiększania gospodarstw chłopskich, a także okazała się przydatna przy hurtowym zakupie większej ilości narzędzi rolniczych ${ }^{5}$.

Powstanie i intensywny rozwój tego rodzaju struktur był wyrazem wielkiego społecznego zainteresowania nowymi formami gospodarowania. Stojałowski przyczynił się w ten sposób do wzrostu umiejętności gospodarowania, zwiększenia intensywności produkcji rolnej, zorganizował pomoc przy zakupie tanich środków produkcji, a także wpłynął na ograniczenie spekulacji ziemią. Ten rodzaj działalności zaowocował z czasem wyprowadzeniem chłopów ze swoistego letargu, odrodzeniem w nich poczucia obywatelskiego i zainicjowaniem w Galicji ruchu chrześcijańsko-społecznego.

Pierwszym ugrupowaniem, które można zaliczyć do tego nurtu, było Stronnictwo Chrześcijańsko-Ludowe. Dwa człony nazwy stronnictwa świadczą o tym, że z jednej strony włączyło się ono w nurt zdefiniowany przez Kościół w encyklice „Rerum novarum” (1891), a z drugiej prowadziło swą działalność wśród ludu wiejskiego. Założycielem stronnictwa był ks. Stanisław Stojałowski i jemu zawdzięcza ono śmiały i radykalny program, który wybiega daleko poza swoją epokę, wyprzedzając nawet naukę papieża Leona XIII. Program stronnictwa uznawał w całej pełni władzę papieża, ale przeciwstawiał się pojmowaniu religii katolickiej jako strażniczki interesów państwa i warstw posiadających. Wychodząc z założenia, że „wszyscy jesteśmy dziećmi jednego Ojca”, program przyjmował za obowiązującą demokratyczną zasadę równości. Uznawał także prawo do własności i zabezpieczenia bytu rodziny, pracę zaś rozumiał jako powszechny obowiązek i źródło wszelkiego bogactwa. W związku z tym nikt nie powinien być pozbawiony owoców własnego trudu. Kolejne punkty programu stanowiły, że rodzinie przysługuje nienaruszalność praw, a państwo ma charakter służebny w stosunku do społeczeństwa. Spośród innych ważnych postulatów należy wymienić: ochronę matki

${ }^{5}$ F. Kącki, Ks. Stanisław Stojałowski i jego działalność społeczno-polityczna. T. 1 (1845-1890), Lwów 1937, s. 51 („Badania z Dziejów Społecznych i Gospodarczych”, nr 31); A. Zakrzewski, Od Stojałowskiego do Witosa, Warszawa 1988, s. 13-15; J. Kuś, Ks. Stanisław Stojałowski na Śląsku Cieszyńskim, „Studia Teologiczno-Historyczne Śląska Opolskiego" 1976, nr 5, s. 169-170. 
i dziecka, bezpłatną naukę w szkołach, zakaz przedwczesnej pracy dzieci, ochronę społeczeństwa przed lichwą. Program domagał się ponadto reformy prawa własności i dziedziczenia celem sprawiedliwego podziału dóbr, wolności polowania i rybołówstwa, ośmiogodzinnego dnia pracy, minimum płacowego i ubezpieczeń społecznych ${ }^{6}$.

Mimo że zarysowana wyżej działalność związana z powołaniem do życia stronnictwa politycznego stanowi istotny szczegół biografii ks. S. Stojałowskiego, to jednak pozostałe dokonania lokują go w rządzie wybitnych przedstawicieli ruchu chrześcijańsko-społecznego.

Nawet pobieżna charakterystyka działalności ludowej ks. Stojałowskiego powinna uwzględniać trzy elementy stanowiące podstawę do realizowania dążeń. Była to: akcja oświatowa polegająca na zakładaniu czasopism ludowych, akcja gospodarcza prowadzona przez zakładanie wspomnianych kółek rolniczych oraz akcja religijna wyrażająca się m.in. przez aktywność pielgrzymkową ${ }^{7}$. Co do celów politycznych, to Stojałowski walczył o usamodzielnienie chłopów, aby mogli brać udział w wyborach bez ulegania wpływom kół klerykalno-konserwatywnych, bądź administracji państwowej. Narzędziem służącym realizacji tej idei miało być niezależne stronnictwo chłopskie. Realizując powyższy zamysł, Stojałowski był obecny przy powstawaniu i w kierownictwie Stronnictwa Chłopskiego, Stronnictwa Chrześcijańsko-Ludowego, a wreszcie Centrum Ludowego ${ }^{8}$.

Realizacja tak wielu inicjatyw stała się możliwa dzięki m.in. wykorzystaniu prasy katolickiej. Choć Stojałowski również i w tym względzie jako jeden z pierwszych zdecydował się wykorzystać prasę, to warto uświadomić sobie, że Kościół w Galicji dosyć późno otworzył się na ten środek oddziaływania duszpasterskiego. Stało się to dopiero po ogłoszeniu encykliki „Rerum novarum”. Nie wolno jednak zapominać, że wcześniej, bo w latach 60. XIX w. pojawiły się na galicyjskim rynku czytelniczym pierwsze czasopisma popularne dla ludu. Były to: „Wieniec”, „Pszczółka”, „Chata”, „Nowiny”, a na Śląsku Cieszyńskim - „Gwiazdka Cieszyńska”. W Krakowie zaczął wychodzić „Dzwonek”, a od 1893 r. „Nowy Dzwonek” określany

${ }^{6}$ J. Pawłowski, Stronnictwa i programy polityczne w Galicji. 1864-1918, Warszawa 1966, s. 62-70.

7 J. Stapiński, Pamiętnik, Warszawa 1958, s. 46.

8 K. Wąsowicz, Dzieje Stronnictwa Ludowego w Galicji, Warszawa 1956, s. 38. 
jako pismo ludowe, polityczne i naukowe ${ }^{9}$. W 1893 r. pojawiły się działania zmierzające do założenia katolickiego funduszu prasowego, a od 1897 r. trwały zabiegi o zorganizowanie dziennika katolickiego ${ }^{10}$. Od 1883 r. we Lwowie wychodziło czasopismo „Gazeta Kościelna”, przeznaczone dla księży i inteligencji katolickiej. W 1884 r. pojawił się organ księży jezuitów zatytułowany „Przegląd Powszechny”. Jego redakcja była otwarta na przemiany w dziedzinie religijnej, społecznej, kulturalnej, a nawet politycznej. Publikacje charakteryzowały się powściągliwością i wyważeniem w osądach, a także tolerancją w ramach etyki katolickiej. Twórcy pisma, adresując je do inteligencji, starali się wypracować linię porozumienia między katolicyzmem a nowymi poglądami w nauce, kulturze i sztuce ${ }^{11}$.

Przemiany polityczne i społeczne 1905 r. sprawiły, że kardynał Jan Puzyna założył dla chłopów czasopismo „Prawda”, natomiast dla robotników „Postęp”. Biskup tarnowski Leon Wałęga, obawiając się opanowania ruchu ludowego przez środowiska antykościelne, powołał do istnienia tygodnik „Lud Katolicki”.

Duży wpływ na rozwój ruchu ludowego wywarła prasa. Ks. S. Stojałowski docenił zalety tego nowego medium w dziedzinie kształtowania świadomości i postaw społecznych. W 1875 r. objął redakcję „Wieńca” i „Pszczółki”. Te dwa periodyki odegrały istotną rolę w jego akcji ludowej. Dopełniły ją inne czasopisma i dodatki do pism podstawowych - dla kobiet „Niewiasta”, fachowo-rolnicze - „Gospodarz Wiejski” i „Rolnik”, satyryczne - „Cepy”, dla inteligencji - „Piast” i „Polska”, dla duchowieństwa - „Dzwon” oraz cieszące się dużym zainteresowaniem kalendarze. Pisma ks. Stojałowskiego rywalizowały z niektórymi periodykami katolickimi, a zdarzało się również, że je zwalczały. Tak działo się w odniesieniu

${ }^{9}$ J. Bujak, Wieś zachodnio-galicyjska u schyłku XIX wieku, [w:] Wieś polska, Lwów 1905, s. 96.

${ }_{10} \mathrm{H}$. Jackowski, O potrzebie, programie i założeniu dziennika katolickiego, „Gazeta Kościelna” 1897, nr 19, s. 157-160.

11 Więcej na temat „Przeglądu Powszechnego” zob. Z. Jakubowski, „Przegląd Powszechny” 1884-1985, Warszawa 1987; M. Jagiełło, Trwałość i zmiana. Szkice o „Przeglądzie Powszechnym” 1884-1918, Warszawa 1993; U. Caumanns, Die Polnischen Jesuiten, der „Przegląd Powszechny” und der politische Katholizismus in der Zweiten Republik. Ein Beitrag zur Geschichte der katholischen Presse Polens zwischen den Weltkrigen (1918-1939), Dortmund 1996; M. Jagiełło, Próba rozmowy. Szkice o katolicyzmie odrodzeniowym i „Tygodniku Powszechnym"1945-1953, Warszawa 2001. 
do innych czasopism ludowych, zarówno lewicujących, jak i nieortodoksyjnych z religijnego punktu widzenia, np. „Przyjaciel Ludu” Bolesława Wysłoucha ${ }^{12}$. Wydaje się, że przyczyną wielu tego rodzaju napięć bywały również przeciwieństwa personalne wydawców różniących się poglądami na realizację tej samej idei.

Prasę galicyjską tego okresu charakteryzowała efemeryczność, to znaczy zmienność i często krótka obecności na rynku czytelniczym. Wydawana z inicjatywy prywatnej, nie dysponowała poważniejszym zapleczem kapitałowym, które czyniłoby ją bardziej stabilną i odporną na ekonomiczne wstrząsy. Rozłamy polityczne również przyczyniały się do zamykania jednych i powstawania innych tytułów. Całości dopełniała chwiejność ideowa wydawców. Przykładem mogą być czasopisma samego Stojałowskiego. Konserwatyści i część duchowieństwa uważała je za radykalne społecznie, a tymczasem zarówno „Wieniec”, jak i „Pszczółka” w winiecie nosiły słowa Zygmunta Krasińskiego: „Z polską szlachtą polski lud" - co świadczyło o tym, że Stojałowski, choć był działaczem chłopskim, to jednak nie zapominał o swoim szlacheckim pochodzeniu ${ }^{13}$.

Mniej liczne były katolickie pisma poświęcone sprawom robotniczym. W 1895 r. zaczęła wychodzić „Pochodnia”, zastąpiona kilka miesięcy później przez wydawany we Lwowie organ robotniczy zatytułowany „Grzmot". Przyczyn pojawienie się katolickiej prasy adresowanej do robotników należy upatrywać w powstającym ruchu socjalistycznym. Do czasopism katolickich, które interesowały się sprawami robotniczymi, należy zaliczyć „Postęp” i „Głos Narodu”. Natomiast wśród pism politycznych powołujących się na wartości chrześcijańskie należy wymienić m.in.: „Dziennik Polski”, „Przegląd”, „,Gazetę Narodową” i „Gazetę Lwowską”. Czasopisma te zostały skrytykowane przez „Gazetę Kościelną” adresowaną do księży i inteligencji katolickiej. Wśród najważniejszych zarzutów wymieniono brak ducha chrześcijańskiego, reprezentowanie partykularnych interesów, oportunizm i zmienność. Nie tylko redakcja wspomnianego periodyku krytycznie odniosła się do wymienionych czasopism, również hierarchia kościelna z dużą powściągliwością spoglądała na wiele

12 J. Bojko, Ze wspomnień, Warszawa 1959, s. 16.

13 Cz. Strzeszewski, Chrześcijańska myśl i działalność społeczna w zaborze austriackim w latach 1865-1918, [w:] Historia katolicyzmu społecznego w Polsce, pod red. Cz. Strzeszewskiego, Warszawa 1981, s. 152. 
czasopism galicyjskich, które w podtytule nosiły przymiotnik katolicki. W 1894 r. biskupi diecezji lwowskiej, przemyskiej i tarnowskiej wspólnie ogłosili list pasterski, w którym umieścili na indeksie nie tylko wspomnianą prasę socjalistyczną, lecz niemal całą prasę ludową, w tym czasopisma wydawane przez ks. S. Stojałowskiego. W liście tym przestrzegali ponadto: „przed samozwańczymi nauczycielami fałszu i przewrotności, którzy narzucają się ludowi na orędowników i kierowników"14.

Wspomniany list był następstwem konfliktu, jaki od kilku lat narastał między ludowcami galicyjskimi a środowiskami kościelnymi Galicji. Genezy tego konfliktu należy upatrywać m.in. w działalności ks. S. Stojałowskiego, szczególnie aktywnej w latach 1875-1890. Działacz, o którym mowa, posługując się prasą adresowaną do środowisk wiejskich, rozwinął akcję oświatową, polityczną i gospodarczą. Organizował zebrania chłopskie, prowadził akcję wyborczą, przyczynił się do wzrostu świadomości politycznej chłopów. Znane było jego hasło wyborcze: „Chłopi wybierajcie chłopów". Tego rodzaju różnorodne formy działalności prowadzone samodzielnie, w oderwaniu od struktur kościelnych, uwikłały go w konflikt z władzą duchowną i świecką. Stojałowski, wykorzystując wspomniane wyżej czasopisma: „Wieniec Polski”, „Pszczółkę” i „Dzwon”, w sposób bardzo zdecydowany odnosił się do przeciwników politycznych i tych spośród duchowieństwa, którzy inaczej niż on pojmowali akcję ludową. Świadczy o tym list otwarty, jaki w 1891 r. na łamach „Tygodnika Katolickiego" zamieścili księża z dekanatu bielsko-bialskiego i oświęcimskiego. Czytamy w nim m.in.:

P.T. ksiądz Redaktor zadarł z całym światem, poróżnił się z władzą duchowną i świecką, a nadużywając wiary i religii, zastawia się nimi, burzy naszą spokojną i uczciwą ludność, sieje wśród niej ziarna niezgody, waśni i rozterek, a siebie rad by otoczyć areolą prawości i męczeństwa [...]. Dopóki gazety księdza Redaktora nie zmienią tonu, dopóki w nich trwać będzie podjudzanie, walka, rzucanie się na wszystkich i na wszystko, dotąd nie chcemy nic mieć wspólnego z „Wieńcem”, „Pszczółką „ „i „Dzwonem”15.

${ }^{14}$ Kronika Kościelna, „Gazeta Kościelna” 1894, nr 1, s. 6.

15 List otwarty, „Tygodnik Katolicki” 1891, nr 21, s. 167-168. 
Ksiądz Zygmunt Lenkiewicz, usiłując wyjaśnić stanowisko księdza Stojałowskiego wobec duchowieństwa i władzy kościelnej, pisał: „Z zarzutów, które ks. Stojałowski czyni duchowieństwu, niepodobna zbyć milczeniem tego, który jest zarówno bolesny jak niesprawiedliwy, że duchowieństwo stoi po stronie tych, którzy lud po większej części uciskają lub podniesienie się jego tłumią"16. W dalszej części swojej wypowiedzi ten sam autor pytał: „Jakim sposobem to podejrzewanie duchowieństwa o niechęć do ludu mogło się w księdzu Stojałowskim wyrobić?” I konkludował, że ks. Stojałowski uważa się za reprezentanta ludu; dla ludu pisał, lud zwoływał na wiece, urządzał pielgrzymki ludowe, więc lud uważa za swoją własność tak dalece, że jeśli ktoś występuje przeciwko niemu to występuje przeciw ludowi ${ }^{17}$. Jednak prawdziwe gromy na głowę redaktora „Wieńca”, „Pszczółki” i „Dzwonu” ściągnął jego list otwarty do duchowieństwa, w którym wyłożył własne poglądy, m.in. na kwestie dotyczące zasad pracy duszpasterskiej, w tym działalności społecznej, a także posłuszeństwa władzom kościelnym ${ }^{18}$. W opublikowanym stanowisku, szczególnie jeśli chodzi o kwestię posłuszeństwa, dopatrywano się braku subordynacji lub wręcz zamachu na część biskupów galicyjskich ${ }^{19}$. Tak zrozumieli słowa Stojałowskiego księża wielu galicyjskich dekanatów. Dali temu wyraz, protestując wobec takiej postawy na łamach prasy. W prasie katolickiej można było przeczytać następujące słowa:

Z początkiem roku 1890 rozesłał był ks. Stanisław Stojałowski do kapłanów Archidiecezji lwowskiej list drukowany, w którym naruszył kardynalne zasady karności kościelnej i uwłóczył czci powinnej swemu arcypasterzowi. [...] Dziś godzi on w te zasady już nie w listach prywatnych ale jawnie i publicznie w swoim „Dzwonie”; dziś zgubną, szkodliwą, gorszącą i zaprawioną sofizmatami działalność swą rozszerzył też na lud wierny, którego mieni się orędownikiem; - dziś przeto pomni ciężkiej odpowiedzialności naszej przed Bogiem, z obowiązku pasterskiego, my podpisani kapłani Archidiecezji lwowskiej, również publicznie za pośrednictwem „Gazety Kościelnej” ponawiamy

\footnotetext{
16 Z. Lenkiewicz, W sprawie oświadczeń, „Gazeta Kościelna” 1893, nr 37, s. 327.

17 Tamże.

18 S. Stojałowski, Sylabus propositionum, „Dzwon” 1893, nr 4, s. 323.

19 Tamże, s. 325.
} 
wspomniane wyżej nasze oświadczenia z roku 1890 z tą uwagą, że przyłączamy się w zupełności do ogłoszonych już w tym względzie oświadczeń kapłanów z diecezji tarnowskiej opublikowanych w październiku $1893 \mathrm{r}^{20}$

Stojałowski po raz pierwszy surową naganę otrzymał w grudniu 1877 r. Władze kościelne zarzuciły mu, że jego postępowanie było przeciwne porządkowi i karności. Jako że tego rodzaju urzędowe reprymendy nie były w stanie utemperować ostrza jego wypowiedzi, arcybiskup lwowski Seweryn Morawski wszczął proces kanoniczny i 17 marca $1894 \mathrm{r}$. obłożył go suspensą ${ }^{21}$, potępiając tym samym wydawane przez niego czasopisma $^{22}$. W periodyku będącym urzędowym organem kurii lwowskiej można było przeczytać następujące słowa:

Pisma periodyczne drukiem ogłaszane „Wieniec Polski”, „Pszczółkę” i „Dzwon” jako wielce zgubne, szkodliwe i niebezpieczne nie tylko potępiliśmy, lecz zarazem zakazaliśmy pod grozą kar kościelnych wiernym pisma te czytać, wspierać, prenumerować lub rozszerzać ${ }^{23}$.

Wyrok biskupi zastał księdza S. Stojałowskiego w Rzymie, wykorzystał więc sytuację i 20 kwietnia 1894 r. zjawił się w Kongregacji Świętego Oficjum z pisemną deklaracją uległości i posłuszeństwa władzy kościelnej. Cztery miesiące później, gdy Kongregacja odstąpiła od prowadzenia jego sprawy, przekazując ją właściwym władzom diecezjalnym, Stojałowski skierował na ręce swojego biskupa pismo, w którym przyznaje, że: „ostro i gwałtownie przeciw powadze i władzy biskupów wystąpił”, ponadto w niektórych artykułach „zbyt namiętnie przeciw ludziom wyższych stanów i bogatym występował, co mogło dać słuszny powód do przypusz-

${ }^{20}$ Kronika Kościelna, „Gazeta Kościelna” 1893, nr 40, s. 354.

${ }^{21}$ Suspensa-w Kościele katolickim jedna z cenzur,czyli kar naprawczych. Suspensa dotyczy tylko duchownych i zakazuje wykonywania tylko niektórych lub wszystkich funkcji wynikających ze święceń kapłańskich, władzy rządzenia lub praw i funkcji związanych z urzędem. Suspensa zakazuje przyjmowania korzyści (pensje, renty itd.) pociąga za sobą obowiązek zwrotu wszystkiego, co zostało przyjęte bezprawnie, nawet w dobrej wierze (Kodeks prawa kanonicznego 1983, kanon 1333 §1 i §4). Zob. L. F. Cross, E. A. Livingstone, Encyklopedia Kościoła, t. 2, Warszawa 2004, s. 878.

22 Kronika Kościelna, „Gazeta Kościelna” 1895, nr 51, s. 475.

23 J. Zamorski, Ks. Stanisław Stojałowski, Bielsko 1931, s. 54. 
czenia, że na skrajne zdania socjalnych demokratów się zgadza”; w końcu oświadczył, że chce dane zgorszenie naprawić.

Przeto spełniając zakaz odnoszący się do czasopism „Dzwon”, „Wieniec Polski” i „Pszczółka” wraz ze współwydawcami i współpracownikami od wydawania tych pism odstępuje ${ }^{24}$.

Redaktor „Gazety Kościelnej”, pragnąc przybliżyć czytelnikom niezwykle aktualny i na swój sposób „gorący” ze społecznego punktu widzenia kazus księdza S. Stojałowskiego, pytając o wypełnienie zobowiązań, napisał:

Jakoż wyszła w dwa tygodnie później „Nowa Pszczółka” pod względem formy zewnętrznej niczym nie różniąca się od poprzedniej „Pszczółki”. Gdy „Pszczółka zakończyła się na roczniku XX, numerze drugim z 25 sierpnia 1894 r., „Nowa Pszczółka” właśnie z 25 sierpnia 1894 r. rozpoczęła swoje istnienie od razu rocznikiem XX, numerem trzecim... ${ }^{25}$.

Rok później ks. S. Stojałowski został suspendowany na nowo. Postawiono mu następujące zarzuty: „1). Psuje wiarę, 2). Podburza przeciwko zwierzchności świeckiej i duchowej, 3). Jest nieposłuszny rozkazom biskupów i kongregacji rzymskiej"26. Ogłoszono dekret nakładający na niego klątwę imienną zabraniającą wiernym stykania się z nim oraz czytania jego wydawnictw. W sumie ks. Stanisław Stojałowski był kilkakrotnie oficjalnie upominany przez swoich przełożonych, a trzykrotnie suspendowany.

Warto zwrócić uwagę na jego stanowisko wobec czynionych zarzutów. Dopuszczając możliwość nałożenia na niego kar kościelnych twierdził, że gdyby taki fakt nastąpił, byłby „klątwą polityczną a nie religijną”. Gdy to się stało, uznał, że nałożona na niego kara ma podłoże polityczne

${ }^{24}$ Z. Lenkiewicz, Ostatnie dwa lata w życiu i w pismach «Księdza Redaktora», ,Gazeta Kościelna” 1895, nr 51, s. 475.

25 Tamże, s. 478.

${ }^{26}$ H. Hempel, Wspomnienia z życia śp. Ks. Stojałowskiego, Kraków 1921, s. 27; J. Wołczański, Listy ks. Stanisława Stojałowskiego do arcybiskupa Józefa Bilczewskiego z lat 1901-1902, „Nasza Przeszłość. Studia z dziejów Kościoła i kultury katolickiej w Polsce” 1998, nr 90, s. 387-411. 
i trzeba ją traktować jako „zwyczajny akt polityczny”. Interpretację sytuacji, w której się znalazł, wyłożył w liście do posła galicyjskiego Franciszka Kaczmarka. Pisał w nim m.in.:

To co biskup nakazuje wtedy jest przykazaniem Kościoła, gdy się tyczy rzeczy kościelnych i wydane jest zgodnie z prawem Kościoła i po myśli Namiestnika Bożego, inaczej jest rozporządzeniem ludzkim, to jest osoby, która jest biskupem, a nie biskupiego urzędu ${ }^{27}$.

Powyższe słowa rzucają wiele światła na istotę konfliktu między księdzem Stojałowskim a hierarchią Kościoła katolickiego w Galicji. W przekonaniu organizatora ruchu ludowego decyzje władzy diecezjalnej nie mogły go obowiązywać w tym, co dotyczyło jego działalności społeczno-politycznej. Powyższe przekonanie kłóciło się jednak z oczekiwaniem biskupów, którzy żądali od niego pełnej subordynacji, również w zakresie spraw społeczno-politycznych.

Nałożenie kary na ks. S. Stojałowskiego wiązało się z publicznym odczytaniem stosownego dokumentu we wszystkich kościołach Galicji. Wincenty Witos, przywódca galicyjskich ludowców, zanotował w swoim pamiętniku następujące słowa:

Klątwa na księdza Stojałowskiego za nieposłuszeństwo władzy duchownej zrobiła w powiecie niesłychane wrażenie. Podczas odczytywania jej w kościele rozlegały się głośne płacze i przytłumione szlochania. Ta klątwa, jak i ceremoniał zastosowany przy jej odczytywaniu robiły prawdziwą grozę i przestrach, ale równocześnie też wzbudzały nie tylko zaciekawienie, ale cichy zacięty bunt, żal do władzy i sympatię do wyklinanego. Ks. Stojałowski stawał się dla chłopów jakąś wielką legendarną postacią budzącą z jednej strony obawę, lecz z drugiej rosnący dla niego z dnia na dzień szacunek ${ }^{28}$.

Stojałowski, zabiegając w Rzymie o zdjęcie z niego kar kościelnych, które w 1896 r. podpisali wszyscy biskupi galicyjscy (lwowski, tarnowski, przemyski i krakowski), nawiązał kontakt z francuskimi liderami

27 J. Zamorski, dz. cyt. s. 54.

${ }^{28}$ W. Witos, Moje wspomnienia, t. 1, Paryż 1964, s. 230. 
ruchu społecznego. Umożliwiła mu to hrabina Jadwiga Zamojska, dzięki której mógł udać się do Francji. Tam spotkał się z księżmi demokratami (P. Daudet, Juliusz Auguste Lemie, Emmamuel Boyreau), a także poznał się z chrześcijańskimi działaczami społecznymi (Leon Harmel, H. Lorin). W środowisku francuskim spotkał się ze zrozumieniem i uzyskał poparcie dla swej działalności społecznej. W Galicji natomiast obowiązywał zakaz czytania jego publikacji. Aby odpowiedzieć na pytanie formułowane przez księży i wiernych diecezji tarnowskiej: „Czy zniesienie ekskomuniki nałożonej na księdza Stojałowskiego zawiera w sobie pozwolenie czytania pism przez tego kapłana wydanych?" konsystorz biskupi w prasie zamieścił specjalną notę. Drukowała ją m.in. „Gazeta Kościelna”. Można było w niej przeczytać następujące słowa:

Odpowiadamy - Nie. Zakaz tedy czytania, trzymania i rozszerzania owych pisemek mimo zniesienia exkomuniki trwa w swej mocy. Wzywamy tedy duchowieństwo a mianowicie spowiedników, aby przestrzegali wiernych przy każdej sposobności, iżby się nie ważyli przyjmować, czytać i słuchać owych pisemek pod grozą zaprzeczenia absolucji nieposłusznym ${ }^{29}$.

Dokonując podsumowania dotychczasowych rozważań, trzeba powiedzieć, że sytuacja, w jakiej znalazł się ks. S. Stojałowski uwikłany w konflikt z władzami kościelnymi, wyraża napięcie, jakie istniało w zaborze austriackim między założeniami ideowymi ruchu ludowego a programem działalności społeczno-chrześcijańskiej reprezentowanym przez biskupów galicyjskich. Przywódcom ruchu ludowego zależało na usamodzielnieniu się niezależnego stronnictwa chłopskiego, które powstało w 1892 r. z inicjatywy ks. Stojałowskiego. Episkopat natomiast dążył do podporządkowania sobie tej formacji politycznej działającej na wsi. W tym kontekście następowała coraz większa eskalacja radykalnych postaw wśród chłopstwa. Proces ten podsycała postawa wielu duchownych, którzy krytykowali z ambon działania ludowców. Zdarzało się, że zabraniali im wstępu do kościoła, a nawet odmawiali spowiedzi ${ }^{30}$.

${ }^{29}$ Kurenda Konsystorza biskupiego. Tarnów 23. III. 1898 r., „Gazeta Kościelna” 1898, nr 14, s. 105.

30 D. Olszewski, Szkice z dziejów kultury religijnej, Katowice 1986, s. 285. 
Szczególnym świadkiem zarysowanych wyżej zjawisk była prasa katolicka. Periodyki wydawane przez księdza S. Stojałowskiego służyły budzeniu świadomości społecznej i narodowej w Galicji, wychowywały przyszłych działaczy ludowych. Z czasem podzieliły los swojego wydawcy, na którego nałożono kary kościelne. Czasopisma rekwirowano w drukarni lub niszczono w urzędach pocztowych. Zabraniano je czytać, przechowywać i rozpowszechniać. Zdarzało się, że ich redaktor słyszał słowa: „Przestań się bawić gazetkami, a będziesz miał spokój”31.

Wincenty Witos, dokonując oceny działalności księdza Stanisława Stojałowskiego, twierdzi, że należy mu się pierwsze miejsce, jeśli chodzi o zaangażowanie w pracę nad „budzeniem śpiącego snem wiekowym chłopstwa". Tej prawdy nie zmienią ani jego błędy, ani przewinienia jakie mu zarzucano. Takiego dzieła mógł dokonać tylko ktoś taki, jak młody wówczas proboszcz z Kulekowa. Pomogły mu w tym obrany stan życia, odbyte studia krajowe i zagraniczne, nadzwyczajne zdolności oratorskie, wytrwałość w pracy, zapał i poświęcenie. Spoglądając na tego człowieka trzeba wziąć pod uwagę jego wytrwałość, a także odporność na oszczercze zarzuty, jakich mu nie szczędzono ${ }^{32}$.

Spoglądając dziś na ks. Stanisława Stojałowskiego trzeba powiedzieć, że pozostanie on osobą kontrowersyjną, a zdania historyków na jego temat są podzielone. Podczas gdy jedni podkreślają doniosłość jego działalności w rozwoju galicyjskiego ruchu ludowego, inni uważają go za demagoga ludowego. Niezależnie od wszystkiego, pozostawił po sobie wrażenie osoby barwnej, dynamicznej, o otwartym umyśle, zdolnym do sięgania po nowe idee i wprowadzania ich w życie przy wykorzystaniu nowoczesnych mediów, nawet jeśli wiązało się to z trudnościami i ograniczeniami.

31 J. Pierzchała, Suspensio offitio et sacris, „Opcje. Kwartalnik Kulturalny” 1997, nr 2, s. 108-109.

32 D. Olszewski, dz. cyt., s. 369-382. 


\section{Attitude of the ecclesial leadership to the peasant movement in Galicja, on the basis of the social and publishing activity of Rev. Stanislaw Stojalowski}

ABSTRACT: The end of the $19^{\text {th }}$ century and the early years of the $20^{\text {th }}$ brought important changes in political and socio-religious attitudes in Polish society. They were especially noticeable among the peasants of Galicia. This was connected with the development of the peasant movement there in the last decade of the $19^{\text {th }}$ century, with strong encouragement from the clergy. Rev. Stanisław Stojałowski was an important representative of that movement. He took part in the founding of Stronnictwo Chrześcijańsko-Ludowe (The Christian Folk Party); among other things he organized Towarzystwo Kółek Rolniczych (The Society of Agrarian Cooperatives). Understanding the role of press in forming social consciousness and attitudes, he took over the editorship of "Wieniec" (The Garland) and "Pszczółka" (The Bee). These two periodicals played an important role in his activity. The independent opinions on social questions he expessed caused him to be subject of strong opposition and made his editorial and publishing work more difficult.

KEYWORDS: “Pszczołka”, “Wieniec”, Catholic clergy, Galicia, peasant movement, publishing activity, Stojałowski Stanisław $(1845-1911), 19^{\text {th }}$ century, $20^{\text {th }}$ century. 